\title{
Electron microscope studies of gonococci in the urethral secretions of patients with gonorrhoea
}

\author{
N. M. OVČINNIKOV AND V. V. DELEKTORSKIJ \\ From the Department of Microbiology of the Central Institute for Research on Skin and Venereal Diseases, \\ Ministry of Health, USSR
}

In previous papers ${ }^{\star}$ the main features of gonococcal structure as seen under the electron microscope were described. The study of gonococci taken from a culture on artificial medium is undoubtedly of importance, since it gives an idea of the structure of the pathogen outside the patient's organism and unaffected by exposure to the body's protective forces. However, study of gonococci from pus taken from patients with gonorrhoea is of considerably greater interest, since it is possible to observe the inter-relationships between the body's cells and the gonococci. The gonococci in the pus are subject to the effect of a whole range of factors: extracellular factors such as the effect of antibodies, non-specific protective factors, and therapeutic preparations. Gonococci inside cells are subject to influences which differ according to the cells into which they have penetrated. It must be assumed that antibiotics have different effects on gonococci inside cells and on those outside cells.

It may now be considered as settled that gonococci enter leucocytes as a result of capture by those cells and not through their own vital activities, and not because they find there favourable conditions for nutrition and are able to consume protoplasm and the nucleus, thus destroying the cell. The question naturally arises whether gonococci inside cells remain viable.

Bronštejn (1922) considered the gonococci inside a cell to be an example of endocytobiosis (life inside a cell). The gonococcus and the leucocyte do surprisingly little damage to each other, and gonococci inside leucocytes remain viable.

To settle this question, Ovčinnikov, Bohenek, and Litvak (1934) carried out a number of experiments which established that the gonococcus remains viable and continues to multiply inside neutrophil

*Ovčinnikov (1968); Ovčinnikov and Delektorskij $(1965,1966,1968)$; Reyn, Murray, and Birch Anderson (1963)

Received for publication April 17, 1971

WHO/VDT/RES/GON/70.46 leucocytes. These neutrophils can continue to phagocytose other micro-organisms. The authors considered that true phagocytosis occurs and is carried to completion inside monocytes.

A large number of leucocytes with phagocytosed gonococci indicates a favourable prognosis for the disease, in the opinion of a number of authors, since increased phagocytosis indicates that the microorganism is weak and that the macro-organism is protecting itself well. Without denying this, Fronstejn (1926) and Ovčinnikov have pointed out that the number of leucocytes with phagocytosed gonococci also depends to a considerable extent on how the material was taken for examination. There are more of them in a drop of urethral secretion which has fallen of its own accord, and fewer in material taken direct from the urethral mucosa, for instance, with a loop. Phagocytosis is also more marked when the microbe is weakened.

In this paper we give the results of electron microscopy of pus from patients with gonorrhoea. The inter-relationships between the gonococcus and leucocytes can clearly be seen when this research technique is used.

\section{Method}

The material was obtained from cultures in preparation for electron microscope examination as described in our previous papers. The method used for processing the urethral secretions was as follows:

The secretions were fixed for 24 hours in buffered glutaric-aldehyde solution by the method of Sabatini, Bensch, and Barrnett (1963), and then fixed with osmium (Fernando and Movat, 1964). The material was dehydrated with increasing concentrations of acetone and embedded in Epon-912 epoxide resin by the method described by Luft (1961). Ultrathin sections were cut with a UEMTP-1 ultramicrotome (USSR) or an LKB ultratome (Sweden). The thickness of the sections ranged from 200 to $800 \AA$. The sections were mounted either on carbon films, or on carbon-stabilised Formvar films, or directly on to a brass grid. Contrast was brought about with an aqueous or alcoholic solution of uranyl acetate with subsequent staining with lead salts (Millonig, 1961). 


\section{Observations}

In preparations from a 24-hour culture on ascitic agar the gonococcus had the appearance seen in Fig. 1 (overleaf).

A diplococcus with a clear-cut, three-layered, scalloped cell wall $(\mathrm{Me})$, two electron-dense layers about $30 \AA$ thick, and one electron-transparent layer between them about $40 \AA$ thick; in the young gonococci the outer membrane had a scalloped appearance.

Between the outer membrane and the cytoplasmic membrane there is a very small space. When some methods are used, it can be seen to be filled with a finely granular mass. Possibly this is a liquid of a proteinic nature and its granular structure is a result of processing during fixation or preparation of the specimen for microscopy. More often this gap is empty and structureless. We then come to the cytoplasmic membrane, which is also three-layered (CM). Abutting directly on this is cytoplasm (C), in which granules of various dimensions and densities-ribosomes (R)-are suspended. It is in these that protein synthesis takes place. The centre of the cytoplasm is occupied by a round or polygonal clear structure without a visible membrane and threaded with strands of DNA-a nuclear vacuole $(\mathrm{N})$. The form and structure of the nuclear vacuole differ according to the stage of division of the gonococcus (Figs 1, 2, and 3). Sometimes the redistribution of the nucleoplasm during division can be clearly seen (Fig. 2). If the section is cut closer to the surface of the gonococcus, the nuclear vacuole may not be visible (Fig. 2). Multiplication of the gonococci occurs under ordinary conditions by division into two parts (diplococcus) (Fig. 4) or four parts (tetracoccus) (Fig. 2), but under pathological conditions, particularly in the L-forms, multiplication by budding can be seen.

Between two cocci there is a septum of finely granular structure (Figs 1, 2, 4, and 5). When diplococci divide, the outer wall grows like a wedge into the cytoplasm (Fig. 1). Not uncommonly, mesosomes in the form of coiled spirals are clearly visible (Fig. 3). They are of lamellar structure and are joined to the cytoplasmic membrane. Their functions are varied and similar to those of the mitochondria, the main one being to provide energy at points of intensified growth.

It will be seen in Fig. 4 that one of the cocci has not divided, but that the nucleus has been redistributed to the poles. All the structural features of the gonococcus are the same as on the previous electromicrograph. A second coccus is divided into two halves. The septum (S) between the two diplococci is very wide and the cell wall (Me) is also wide and scalloped. The ribosomes $(\mathrm{R})$ in the divided diplococci are smaller. They are larger in the undivided coccus.

In addition to the ordinary typical gonococci, in cultures, particularly when they have a tendency to produce L-forms, round bodies are encountered of varying dimensions and with one three-layered membrane (Fig. 1, K). In small bodies the internal pattern is indistinguishable, but as their dimensions increase the same structure appears as is found in the larger specimens. The impression is gained that almost the whole cavity of the gonococcus in the L-form is occupied by a nucleus threaded with DNA strands, while the cytoplasm is only present in an insignificant quantity and has been pushed outwards towards the periphery.

Figs 5, 6, 7, and 8 show L-forms of gonococci from a 24-hour culture of gonococci grown on Moustardier, Brisou, and Perrey medium (without penicillin).

Fig. 5 shows a large coccus. The cell wall is thin and blurred. The nucleoplasm $(\mathrm{Np})$ occupies the whole cell. The DNA is in the form of short fine fibres. The finely granular cytoplasm is situated nearer the periphery. Round the gonococcus are small spherical structures of various dimensions, some of which have only a membrane (CK) while others have in addition a fairly large inclusion (KG). Level with it is part of a huge gonococcus in which the finely granular cytoplasm (G) occupies the whole cell except for the central portion, in which a nucleus (N) with strands of DNA can be seen.

The form and structure of the nucleus in the Lforms and the size and structure of the gonococcus itself differ. Fig. 6 shows part of a huge coccus (L-form) with an evenly reticulate cytoplasm. The cell wall $(\mathrm{Me})$ and the cytoplasmic membrane (CM) are extremely thin. Between them are situated rounded granular structures of various sizes (KG). Outside the cell wall are smaller round structures without a granular pattern in their cytoplasm and with only a membrane. This figure, together with Fig. 7, shows that spherical forms occur inside the gonococcus, underneath the cell wall, and outside it, but the nature of their structure differs somewhat. This may be due to the age of the forms concerned.

The nucleus in the gonococcus in Fig. 8 also occupies the whole cell and is, as it were, mixed up with the cytoplasm; it does not have a clear-cut outline. Between the cytoplasmic membrane and the cell wall is a large elongated sector containing spherical, granular structures (KG) and one large oval body similar in structure to the $L$-form of the gonococcus, but of smaller dimensions. In addi- 
tion, there is a spherical inclusion of smaller size with a membrane in which there is a structure of rounded outline with an apparently granular cytoplasm, inside which is an oval body of darker colour with a clear centre and limited by a membrane (KS). Outside the coccus are small spherical structures, most of which have only a membrane; a few have rounded inclusions in the centre.

For electron microscope studies of gonococci in pus, we used urethral secretions from men suffering from fresh gonorrhoea. The gonococci situated inside the cells (Fig. 9) are of roughly the same appearance as in the culture, but the outer wall has a more marked scalloped appearance and the gonococcus is sometimes surrounded by a large number of round structures of varying sizes with a one-layer or twolayer membrane, some of which are elongated. Some of the bigger ones differ from typical gonococci only in size. As yet it is difficult to say what they represent, but it may be assumed that this is a case of atypical intensified multiplication of gonococci by budding. These structures are situated both outside the cell wall and between the cell wall and the cytoplasmic membrane. Their formation is apparently connected with the cell wall. The polymorphonuclear leucocytes in the pus which do not contain gonococci have pseudopodia (Fig. 10) and are more markedly granular than polynuclears which have phagocytosed gonococci (Fig. 10). The impression is given that, after capturing the gonococci, the polymorphonuclear leucocytes are occupied in digesting them, and that the granules, which with their enzymes play the basic part in breaking down the gonococci and participate in the formation of phagolysosomes, are reduced in numbers.

The gonococci in polymorphonuclear leucocytes may be inside or outside the phagosomes. The phagosomes for the most part have a well-marked membrane (Fig. 11, Mph). The gonococci inside the phagosomes vary in structure, possibly according to the length of time they have been there, the nature of the phagosome enzymes, and the enzymes of the granules which enter it. Fusion of the phagosomes can be clearly seen in Fig. 11. Various enzymes are contained in different granules (Fig. 11). The enzymatic action may proceed from one granule or from several in succession, or from all of them together when those containing the various enzymes fuse.

Around the gonococcus in a number of cases, just as in the extracellular gonococci, there are a large number of spherical structures of varying sizes with a marked membrane. Gonococci are also encountered in the process of fission, with a mesosome and with clear-cut septa (tetracoccus) (Fig. 12). It should be noted that the rounded structures sur- rounding the gonococcus lose their shape and later turn into a homogeneous mass (D), but that the gonococcus itself does not undergo any special changes (Figs 12 and 13). All this shows that inside the polymorphonuclear leucocytes live gonococci apparently undergo little change. However, in individual phagosomes, gonococci are found in a half-brokendown condition or in the form of remnants only (Figs 11 and 12). The study of gonococci inside the phagosomes gives the impression that it is the surface of the gonococcus which mainly suffers.

The fact that in some cases gonococci are lysed, while in others they are preserved and even multiply, can be explained in the following way:

(1) It is possible that only gonococci which have died or become weakened can be lysed, whereas active viable individuals continue to multiply. This view is supported by the fact that during penicillin treatment the number of gonococci undergoing lysis among those phagocytosed is greater than among those situated outside the cells, and the changes in them are also more marked (Figs 14, 15 , and 16). The gonococci inside the phagosomes in patients after the administration of penicillin are in a broken-down state (Figs 14, 15, 16, 17, and 18) (2) Gonococcal lysis occurs when the set of enzymes from the lysosomes corresponds to those which cause their dissolution. After administration of penicillin (a single intramuscular dose of 200,000 units), it sometimes seems that the gonococcus is unaffected. The gonococci are situated, as it were, directly in the cytoplasm. The cell wall and cytoplasmic membrane are clear-cut, the cytoplasm is granular, and the nuclear vacuole undergoes no special changes. Around the gonococcus is a broad rim of loose texture with a homogeneous mass on the periphery, and lamellar inclusions are visible (Figs 19 and 20). The cytoplasm is more electron dense. In one of the halves of the diplococci in Fig. 20 a mesosome is visible. The nucleus is wellmarked. It would seem that under the influence of penicillin the cell wall of the gonococcus first swells and then bursts, losing its scallopped edge but keeping for some time its lamellar structure and simultaneously becoming more electron dense. It is also seen that in the phagosome one of the halves of the gonococcus has undergone no essential change while the other half and the round structures surrounding the gonococcus are lysed (Fig. 21). The granular substance in the polymorphonuclear leucocyte varies in electron density.

After unsuccessful penicillin treatment, a large number of round bodies of varying size and without definite structure (similar to those produced by budding) can be seen round the extracellular gonococci. 


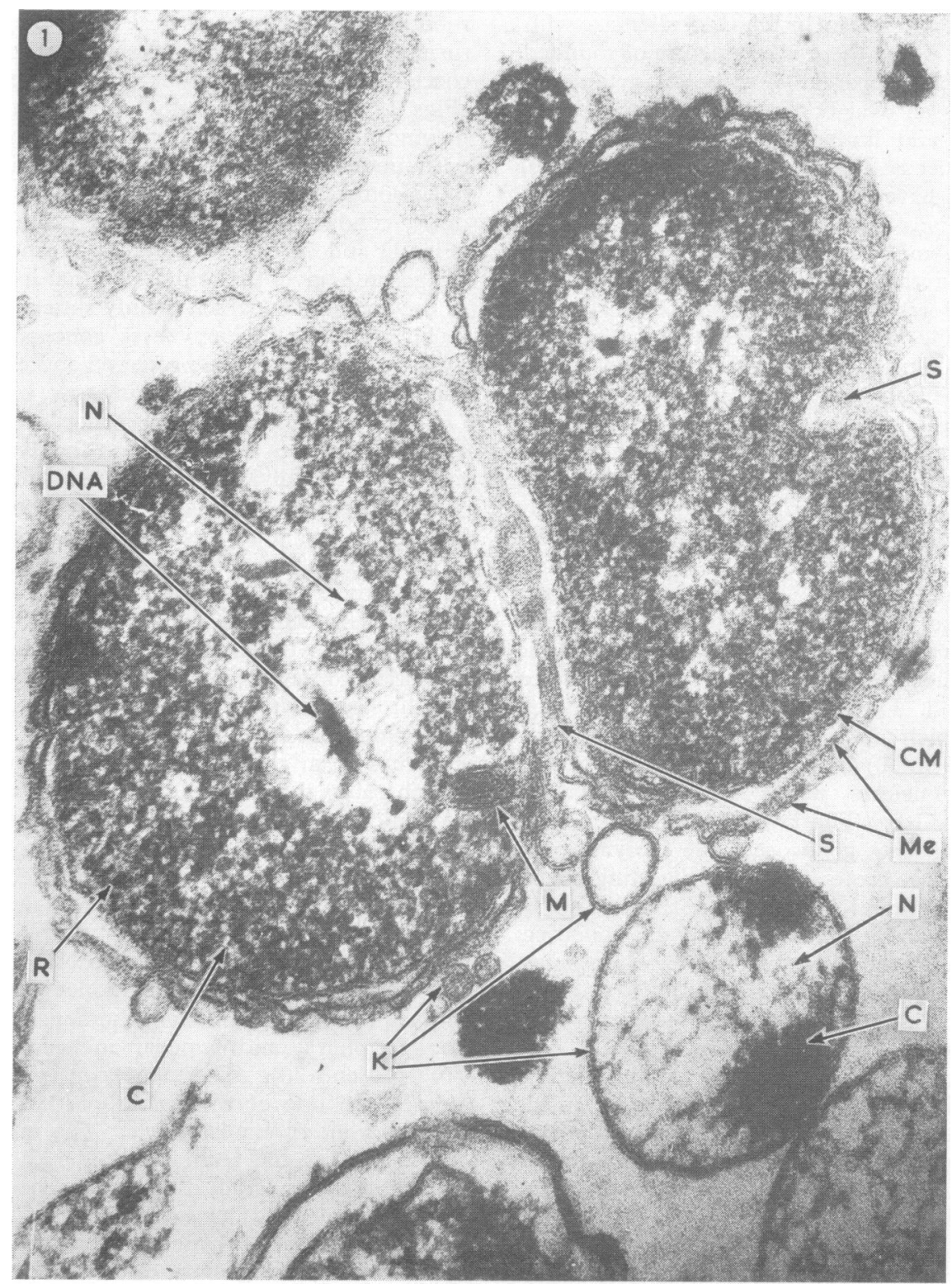

FIG. 1 Ultrathin section of gonococcus from a 20-hour culture on ascitic agar. $\times 100,000$ 


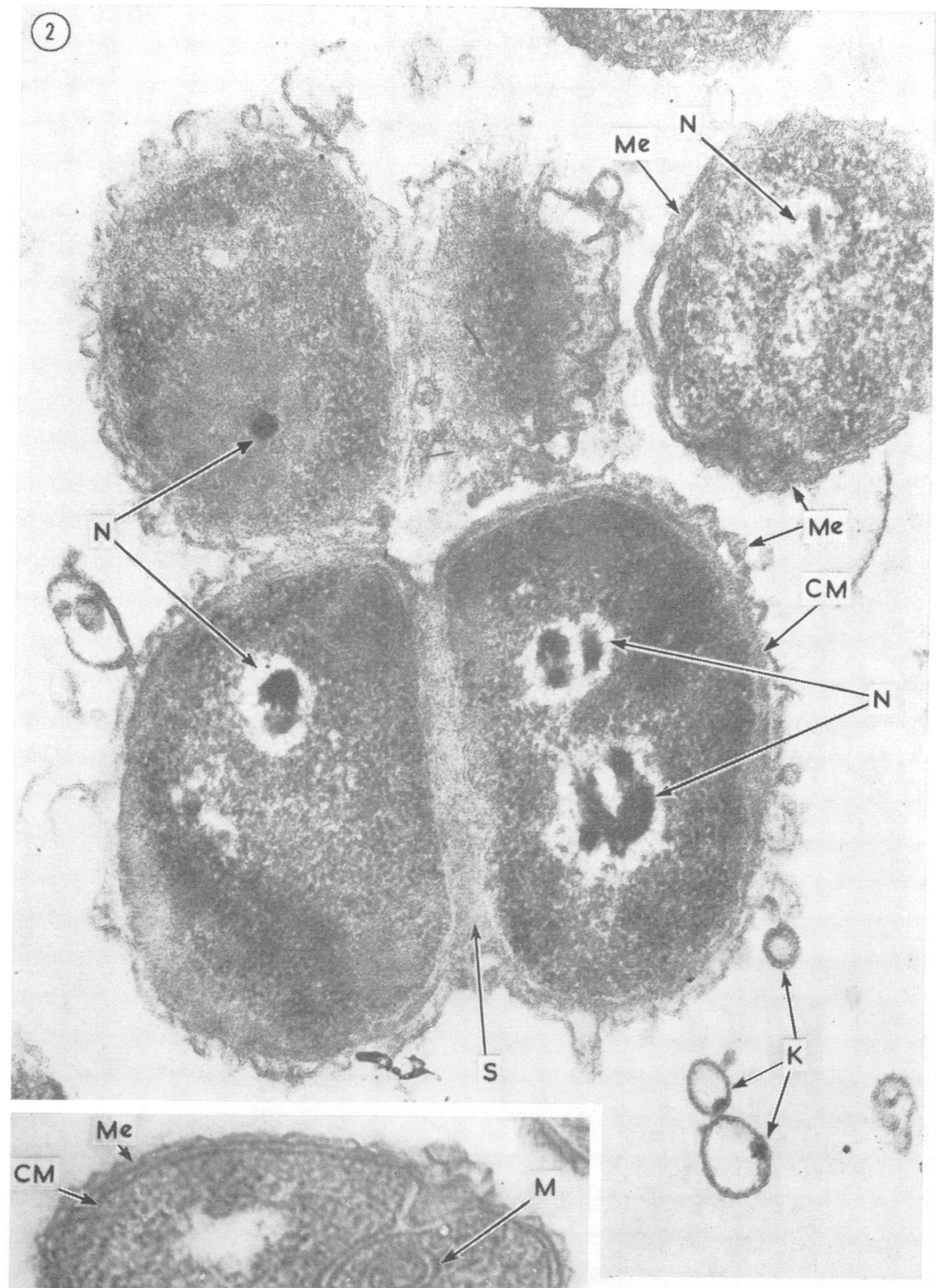

FIG. 2 Ultrathin section of gonococcus from a 20-hour culture on ascitic agar, showing fission of the gonococcus. Tetracoccal form, one pair cut closely to the surface, for which reason nuclear vacuole $(N)$ is invisible. In only one of the cocci is there an electron dense large structure with a large finely granular sector around it. In the second pair of diplococci the nuclear vacuole is at the stage of redistribution of the nuclenplasm before division with clearly-marked strands of $D N A . \times 100,000$ 


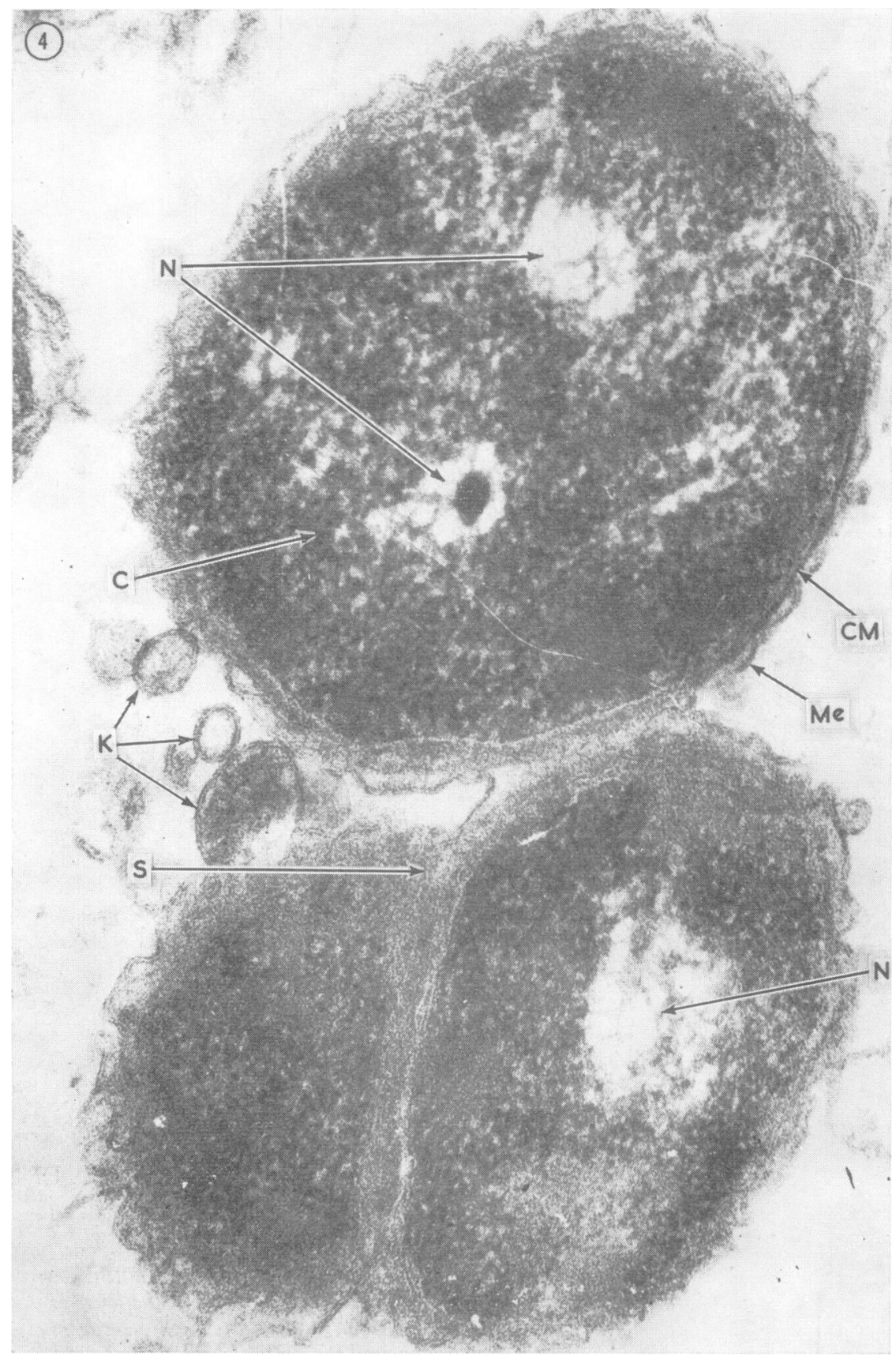

FIG. 4 Division of a gonococcus from a 20-hour culture on ascitic agar. All the structural features are the same as in Figs 1 and $2 . \times 100,000$ 


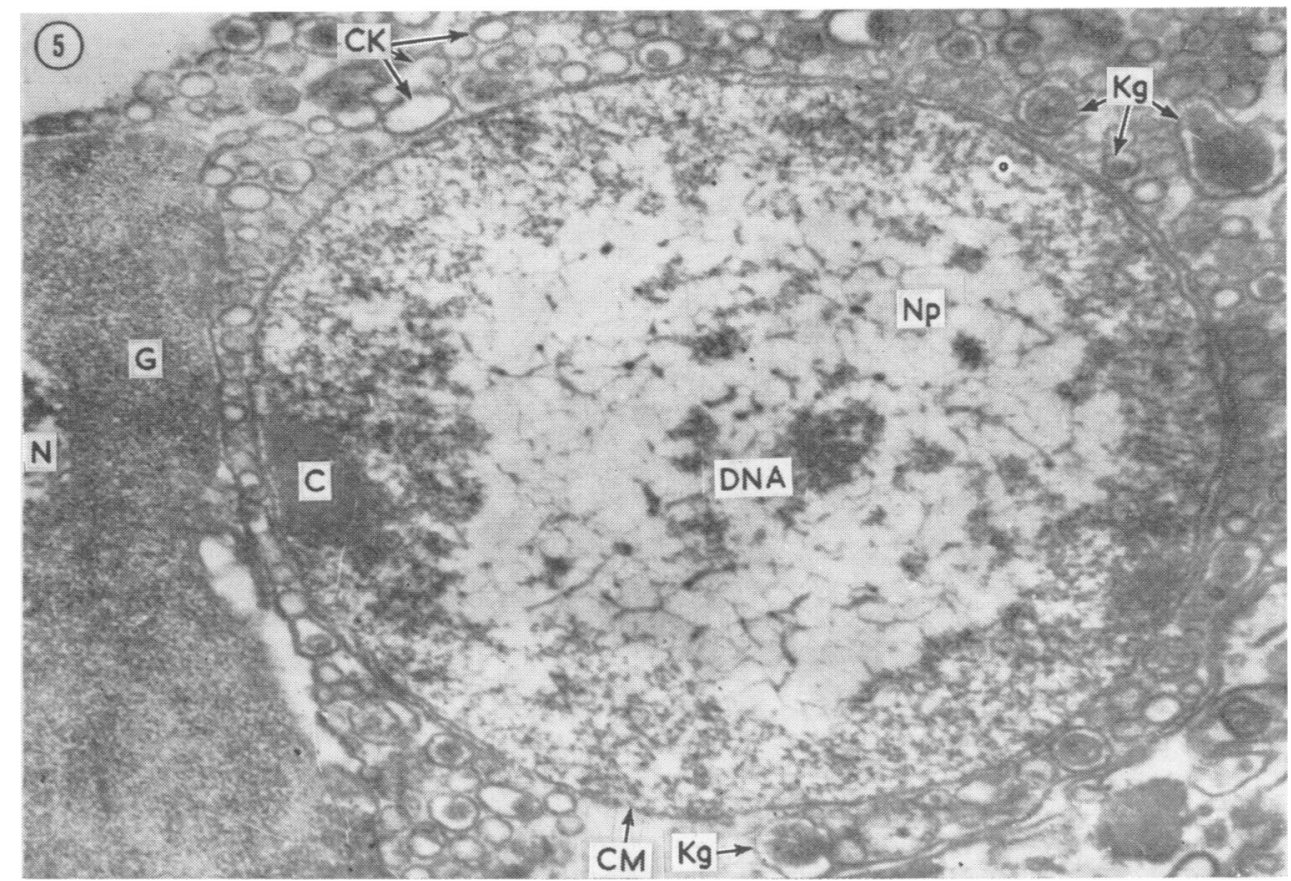

FIG. 5 L-forms of the gonococcus from a 24-hour culture on Moustardier, Brisou and Perrey medium (without penicillin). The cell wall is blurred. It is thin and three-layered (CM). The nucleoplasm $(N p)$ occupies the whole cell. $D N A$ is present in the form of short, fine fibres. Cytoplasm $(C)$ is present in the form of a finely granular substance closer to the periphery. There are small forms round the gonococcus $(\mathrm{Kg}) . \times 60,000$

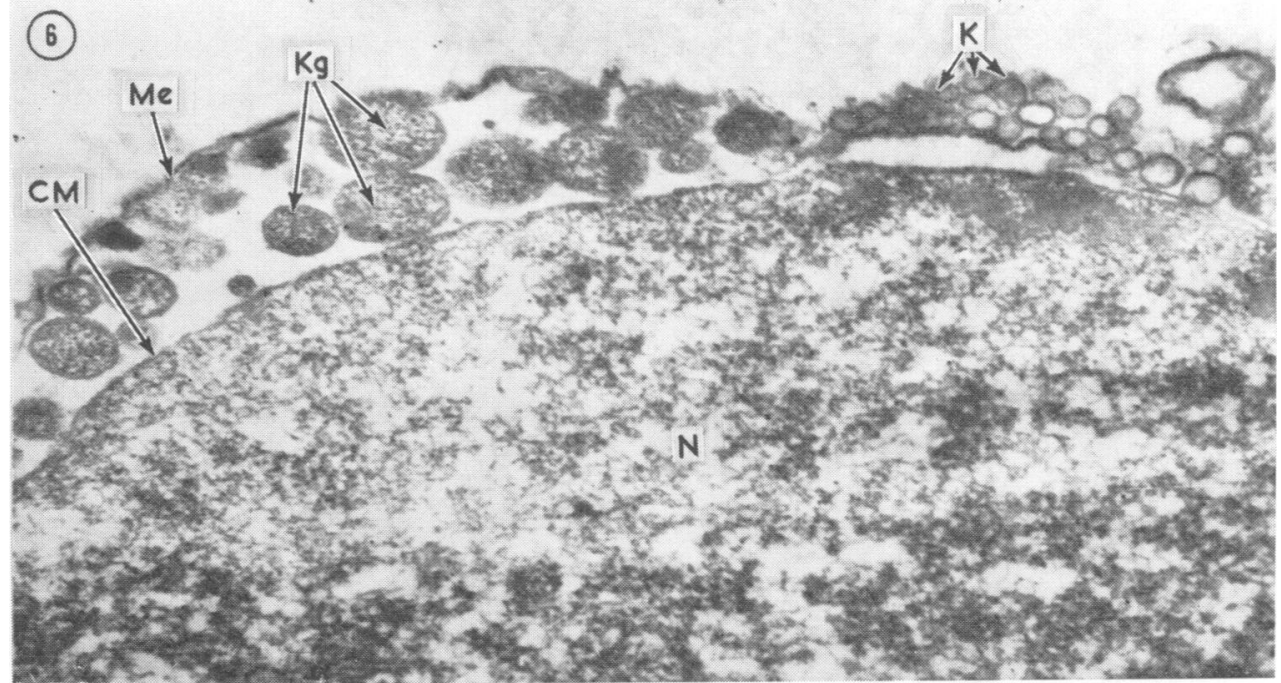

FIG. 6 Ultrathin section of an L-form of gonococcus from a 24-hour culture. Part of a huge coccus in the $L$-form shows an evenly reticular cytoplasm. Rounded forms $(K)$ occur both inside the gonococcus under the cell wall and outside it, but the nature of their structure differs somewhat. $\times 60,000$ 


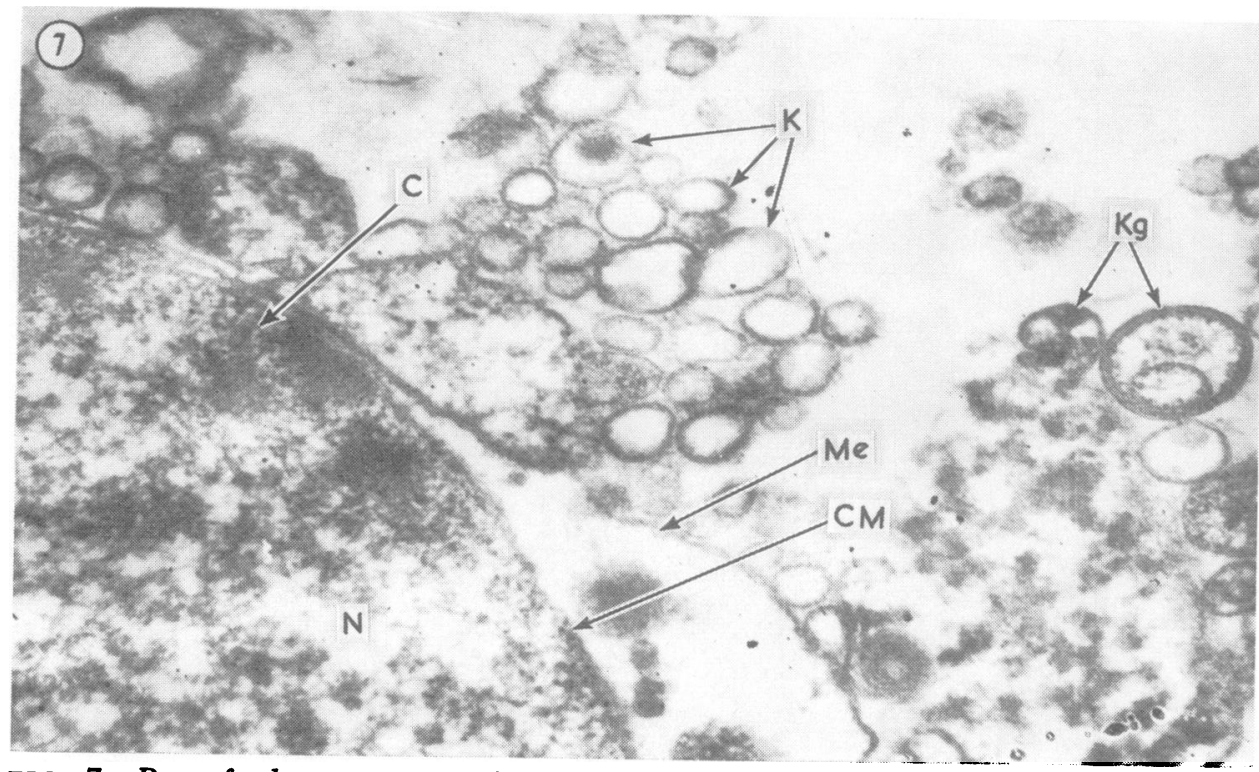

FIG. 7 Part of a large gonococcus in the L-form from a 24-hour culture. Thin cell wall $(M e)$. The nuclear vacuole $(N)$ occupies the whole cell. DNA is present in the form of individual sparse, short threads. The cytoplasm $(C)$ is present in islands in various parts of the cell. Outside the gonococcus there are small, round structures $(K g) . \quad \times 60,000$

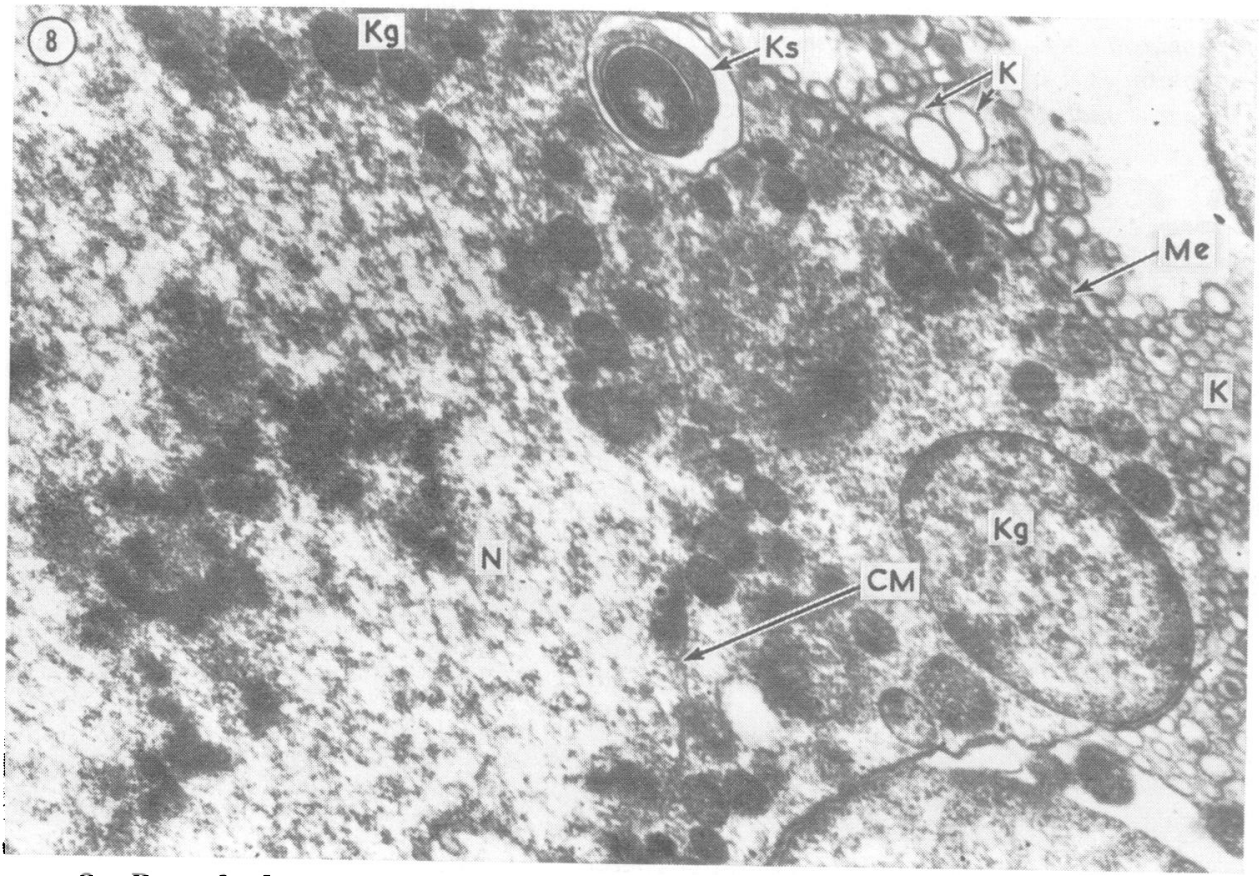

FIG. 8 Part of a large coccus in the L-form. Outside the coccus are rounded small structures $(K)$, most of which have only a membrane. Only a few have rounded inclusions in the centre (Ks). $\times 60,000$ 


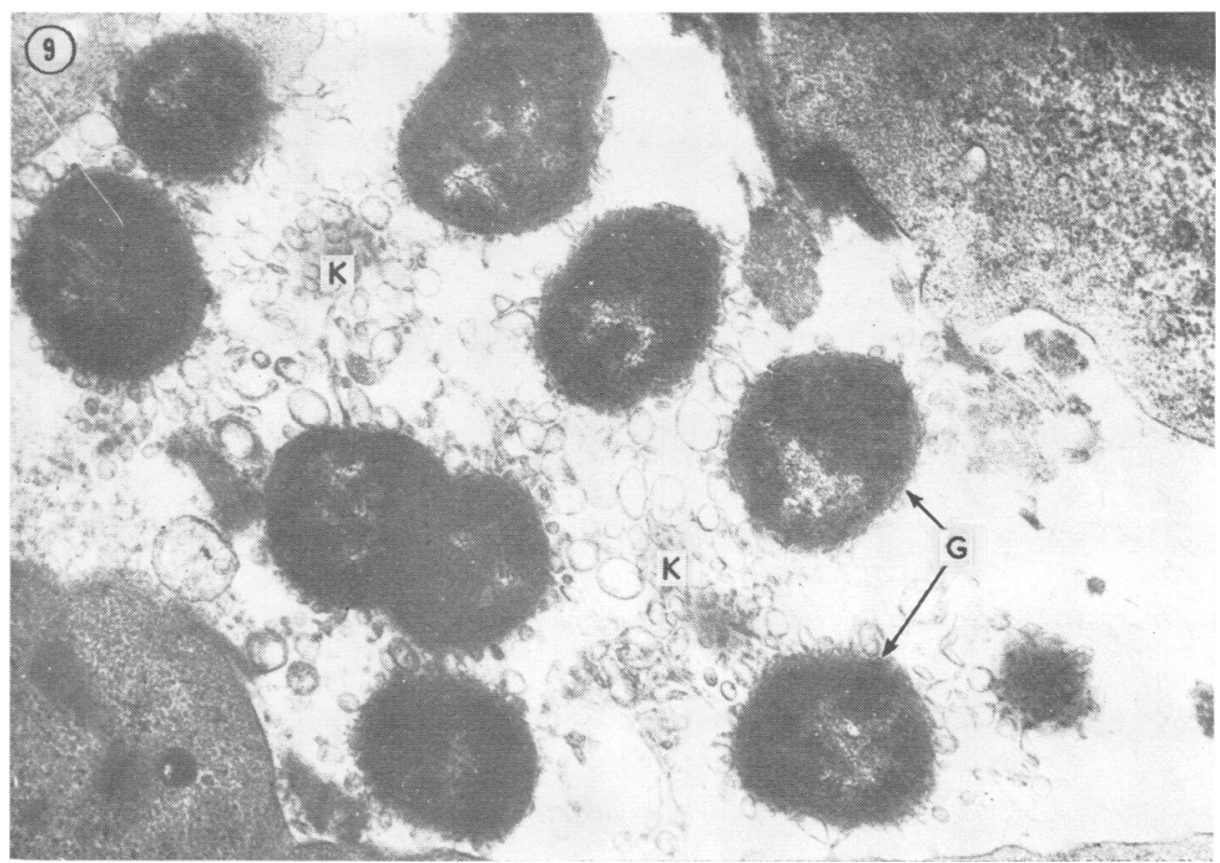

FIG. 9 Ultrathin section. Extracellular gonococci in the urethral secretions of a man suffering from acute gonorrhoeal urethritis. $\times 18,000$

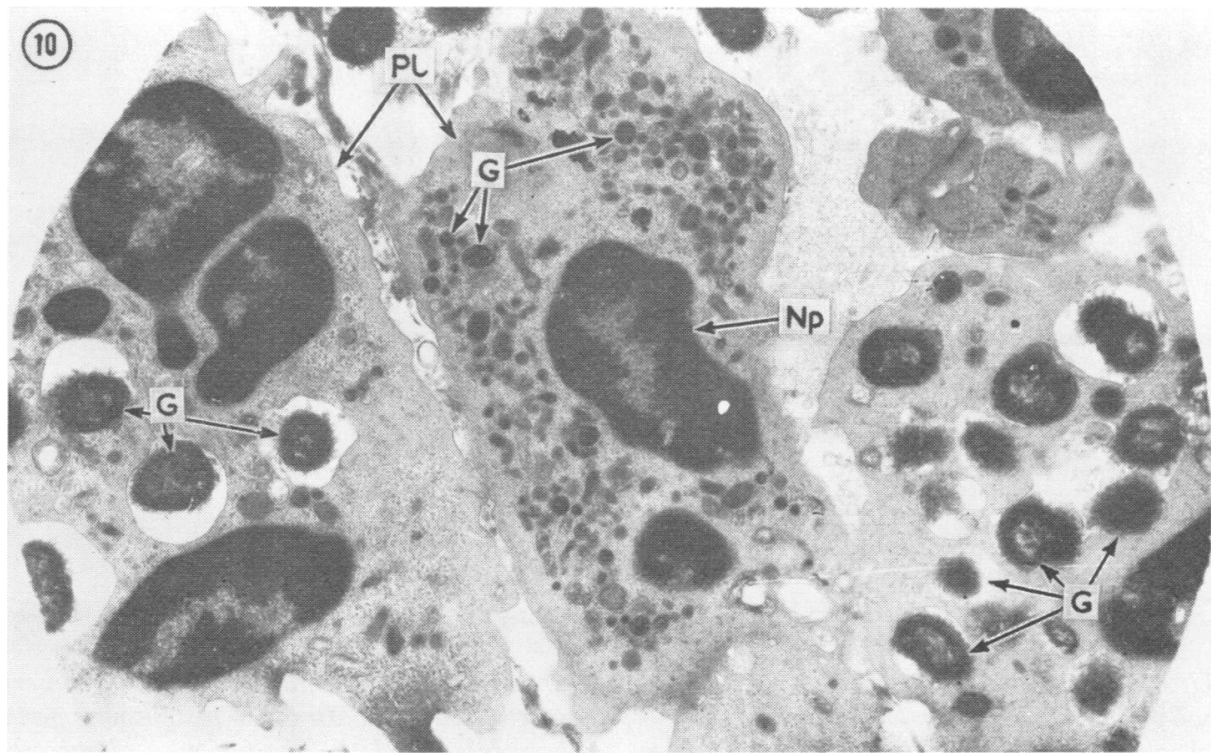

FIG. 10 In the centre there is a polymorphonuclear leucocyte (Pl) without gonococci. In it there are a considerable number of granules $(G)$ of various sizes and electron densities, neucleoplasm $(N p)$ with chromatin on the periphery, and two polymorphonuclear leucocytes with a large number of gonococci inside. Some of them are in the phagosome which is separated from the cytoplasm by a membrane. The impression is given that some of the gonococci occurring in phagosomes are somewhat changed. There are small rounded homogeneous structures around some gonococci. $\times 12,000$ 


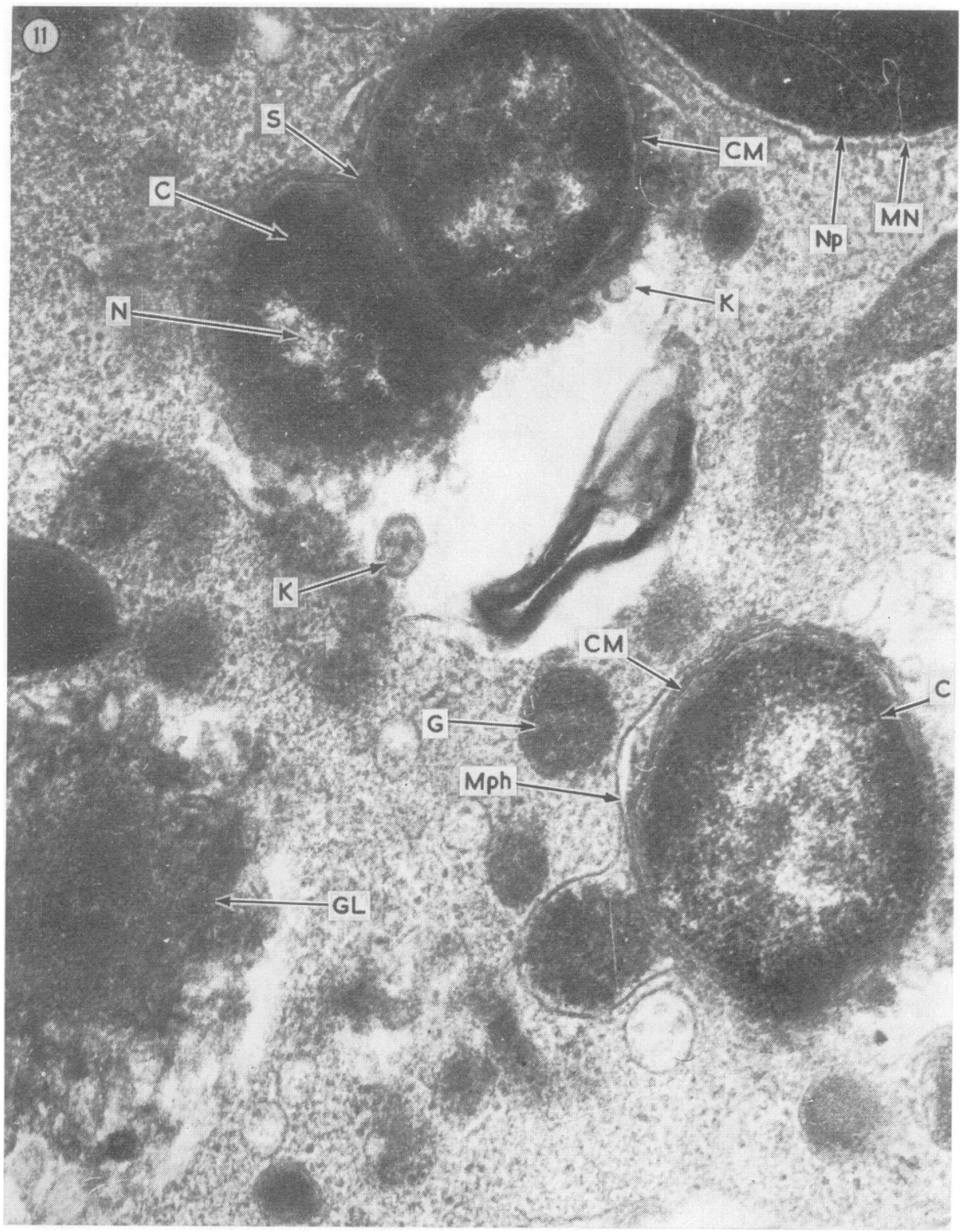

FIG. 11 Ultrathin section. Gonococci inside the phagosomes of polymorphonuclear leucocytes (MNnuclear membrane). The membrane of the phagosomes is well marked (Mph). In some of them, the gonococci are practically unchanged and have conserved their special features. In other phagosomes gonococci have been lysed (GL). The fusion of phagosomes can also be seen. $\times 60,000$ 

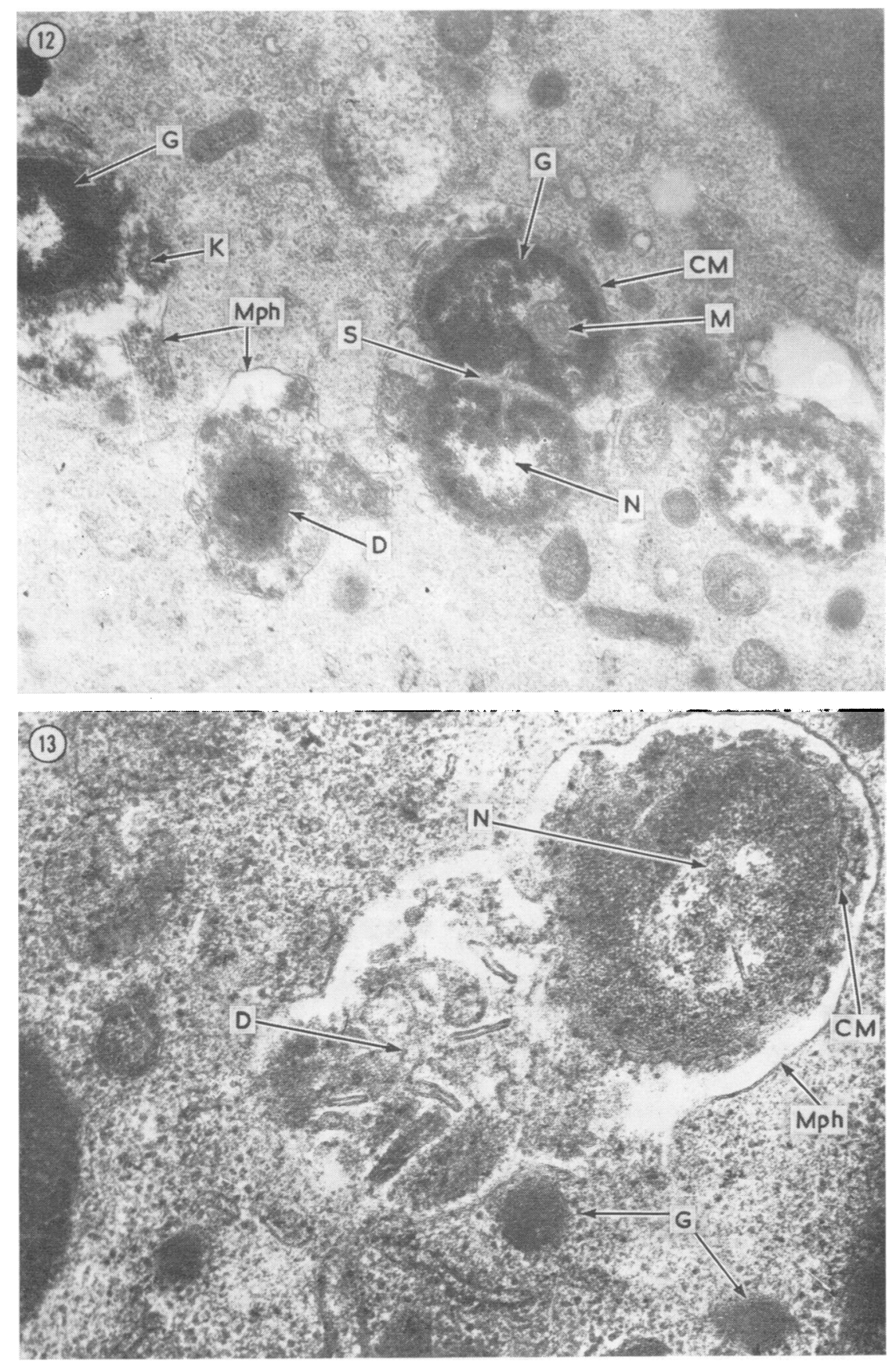

FIG. 12 Gonococci in a polymorphonuclear leucocyte in the secretions from a man with acute gonorrhoeal urethritis. Some of the gonococci found in the phagosomes are little changed. In others the whole peripheral part is, as it were, eaten away and changed into an amorphous mass. The cell wall and the septum $(S)$ which divides off the halves of the diplococcus are well marked. It can clearly be seen where the cell wall has grown into both halves of the diplococcus. Fission was noted and the nuclear vacuole $(N)$ and the lamellar mesosome $(M)$ are clearly visible. On the periphery of the gonococcus there are small rounded structures $(K)$ and occasional elcngated ones. $\times 30,000$

FIG. 13 Gonococcus inside a phagosome of a polymorphonuclear leucocyte from the urethral secretions of a man with acute gonorrhoeal urethritis. In part of the phagosome the membrane has been well preserved, but part of it has been destroyed and its contents have, as it were, poured out into the cytoplasm ( $G=$ granules). The part of the gonococcus underneath the phagosome membrane is little changed, but the nucleus has already lost its clear-cut configuration. The cytoplasm is finely granular and the cell wall is not everywhere intact. In the part of the phagosome where the membrane has been destroyed, there is some sort of amorphous decay (D) and a few crystal-like elongated formations. Possibly these are remnants of a broken-down gonococcus. $\times 60,000$ 

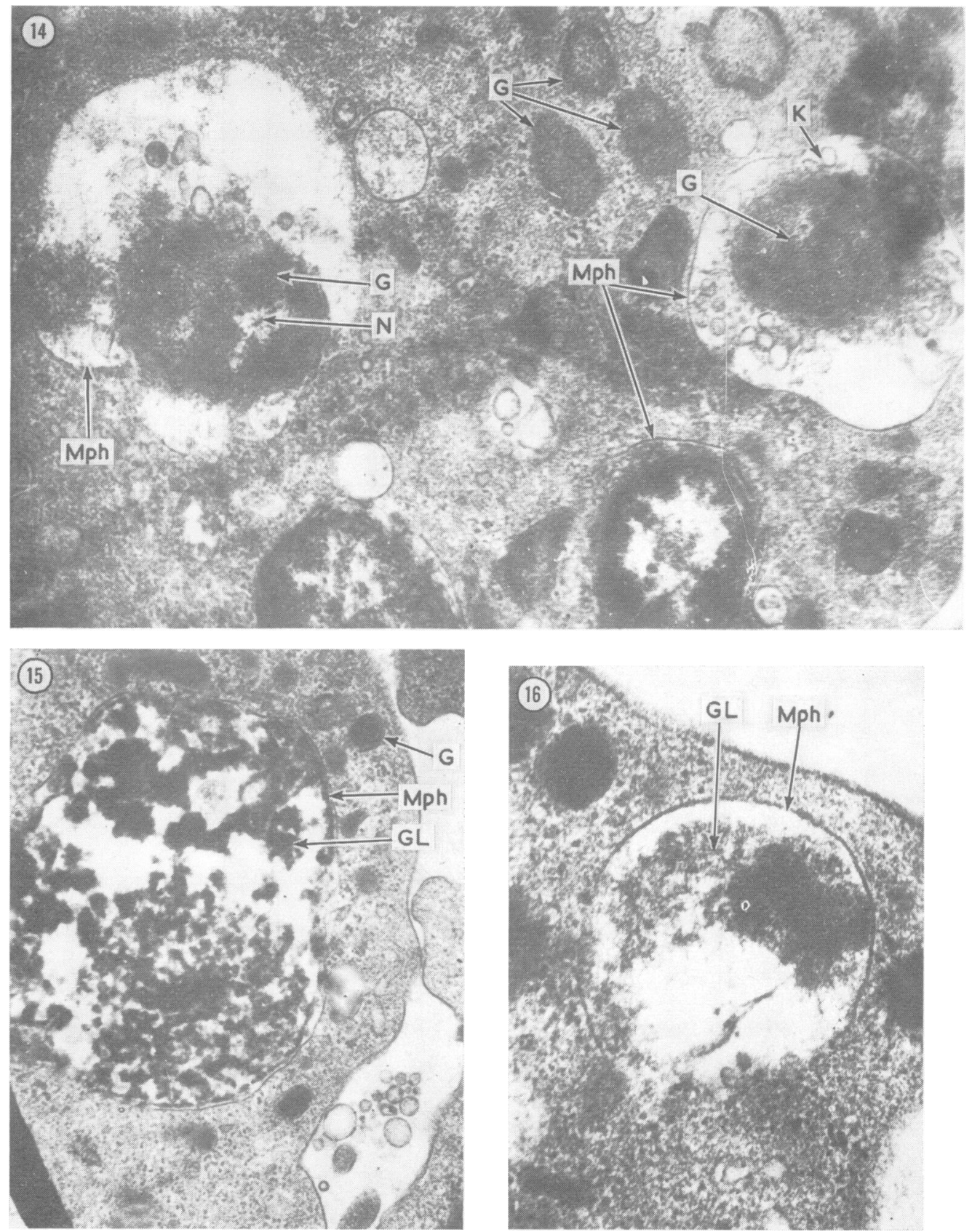

FIGS 14, 15, 16 Ultrathin sections. Gonococci in phagosomes in various stages of destruction in a polymorphonuclear leucocyte from the secretions of a patient with acute gonorrhoeal urethritis, who has

been given one intramuscular injection of 200,000 units of penicillin. The section was made 1 hour after administration of penicillin. $\times 60,000$ 




FIG. 17 Ultrathin section. Phagosome with remnants of a gonococcus in a polymorphonuclear leucocyte from a patient with acute gonorrhoeal urethritis. The phagosome membrane (Mph) is visible. There are remnants of the cell wall and the cytoplasmic membrane (CM). In the centre there are remnants of the nucleus with thick strands of $D N A$ and ribosomes. In the phagosome itself there is an amorphous mass and lamellar ring-like structures (MS). In the lower part of the phagosome, the membrane has been destroyed and it looks as though the contents of the phagosome had poured out into the cytoplasm of the polymorphonuclear leucocytes. The granules $(G)$ are almost pressed up against the phagosome. $\times 100,000$ 


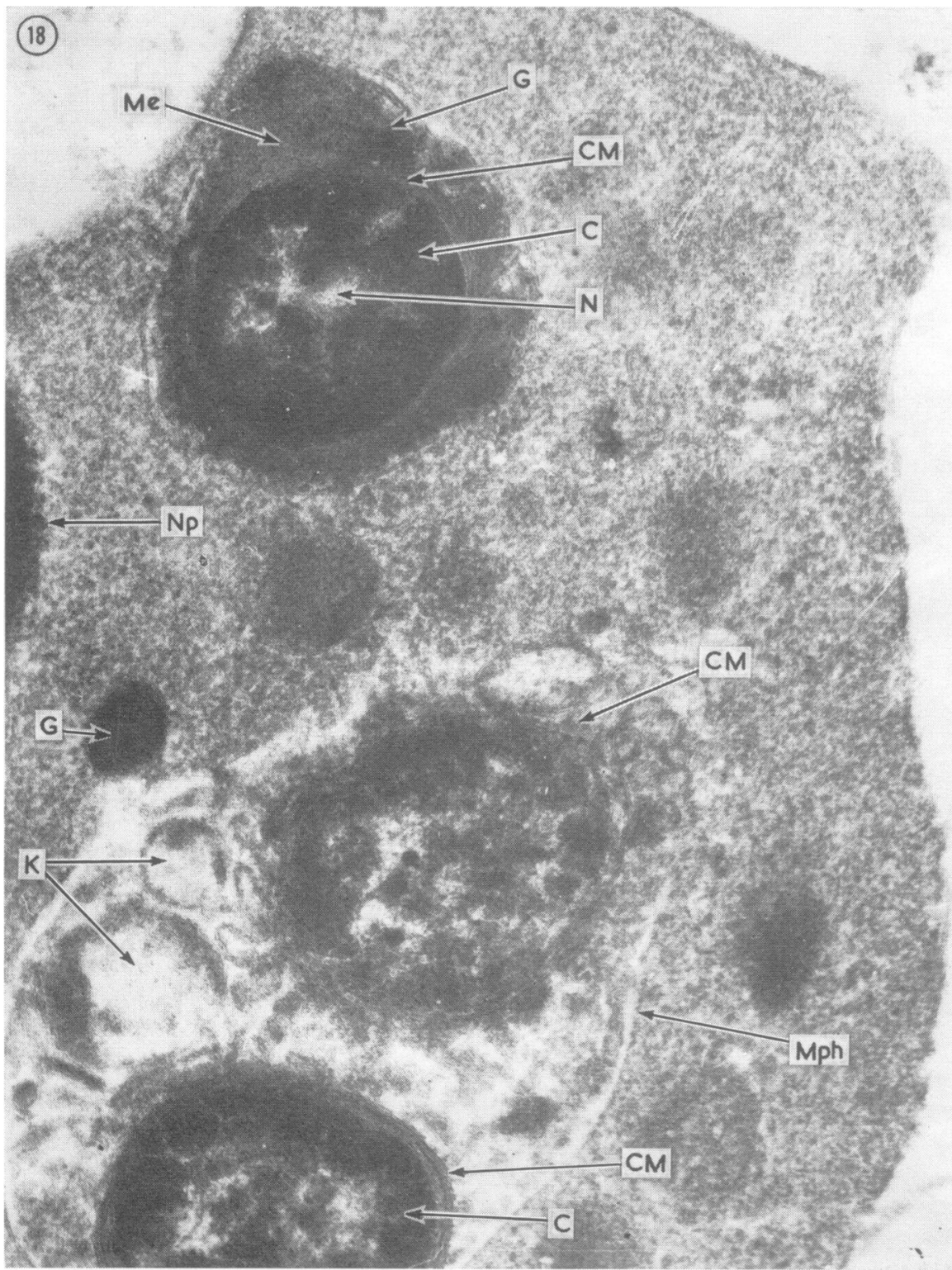

FIG. 18 Ultrathin section. Polymorphonuclear leucocytes from the urethral secretions of a patient who had been given one intramuscular injection of 200,000 units penicillin. The section was made 1 hour after administration of the penicillin. There is a phagosome with a gonococcus. The cell wall and cytoplasmic membrane (CM) are well preserved and 


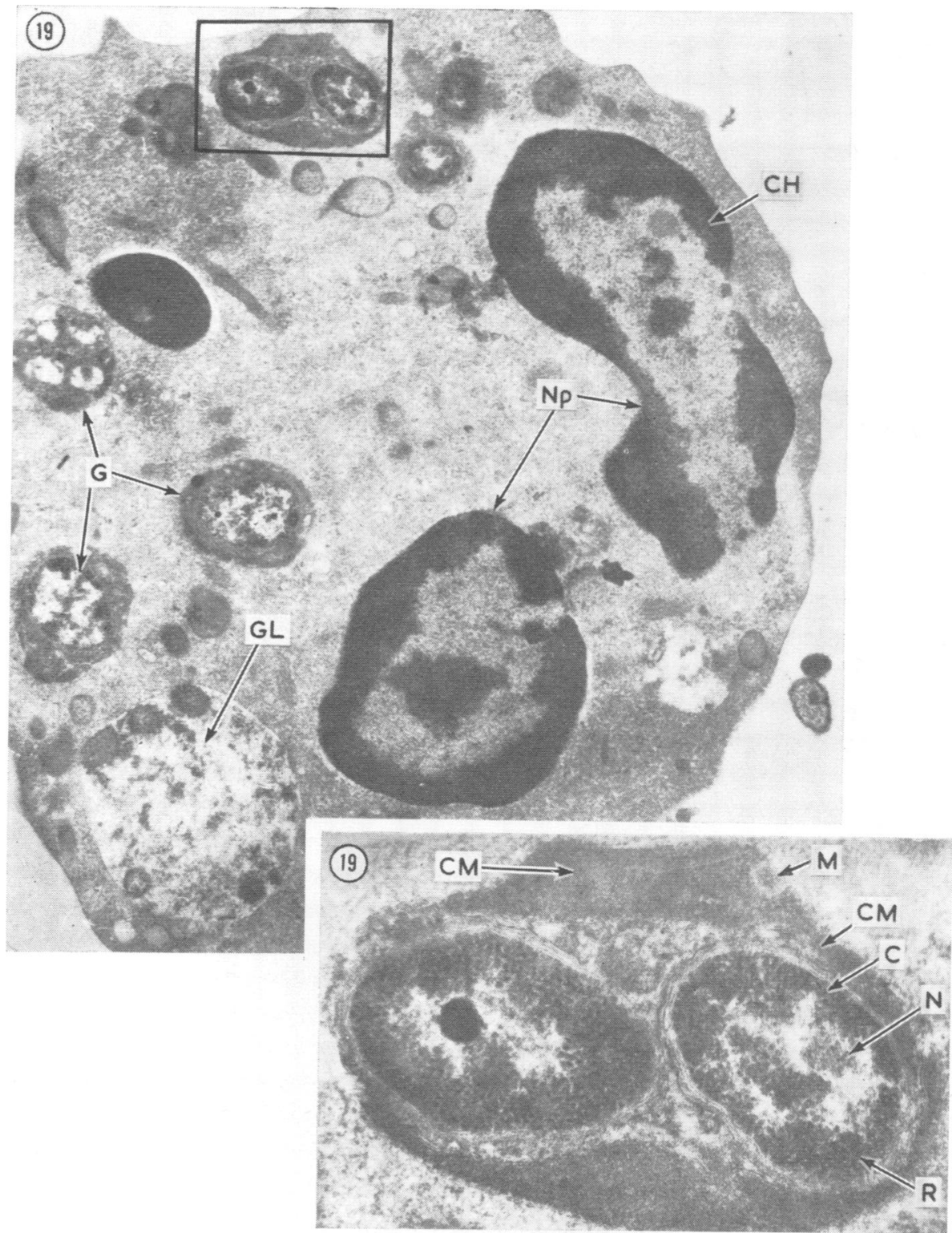

FIG. 19 Ultrathin section. Polymorphonuclear leucocytes with intracellular gonococci from the urethral secretions of a patient with acute gonorrhoeal urethritis, who had been given a single injection of
200,000 units penicillin (CH-nuclear chromatin). The section was made 1 hour after administration of the antibiotic (lower picture-detail) 


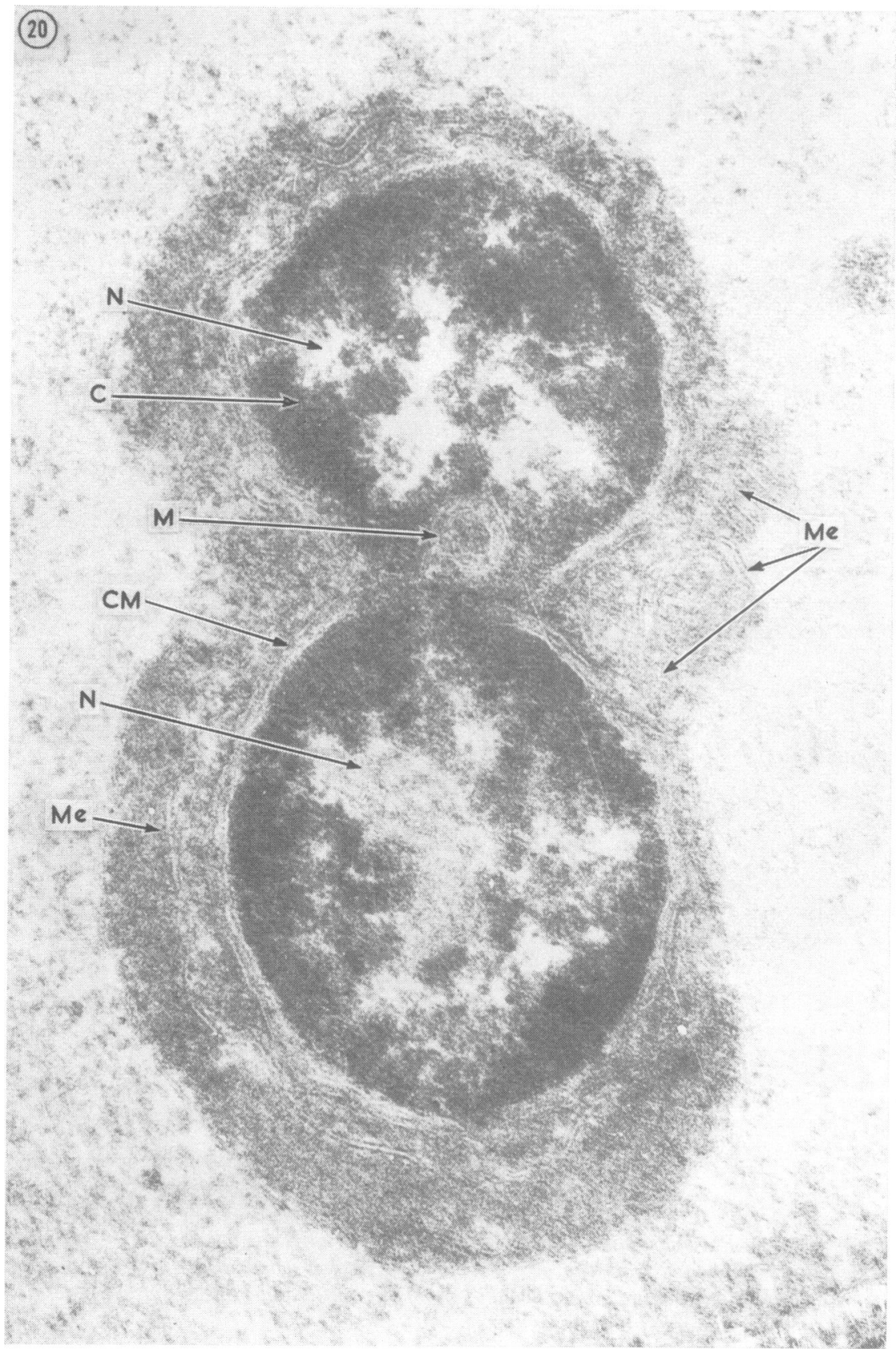

FIGS 20 AND 21 Gonococcus inside a polymorphonuclear leucocyte from a patient with acute gonorrhoeal urethritis who has been given a single intramuscular dose of 200,000 units of penicillin. The preparation was taken 1 hour after administration of the penicillin. $\times 10,000$

A phagosome with remnants of a gonococcus in a polymorphonuclear leucocyte from the urethral secretions of a patient with acute gonorrhoeal urethritis. The phagosome membrane is visible. There are 


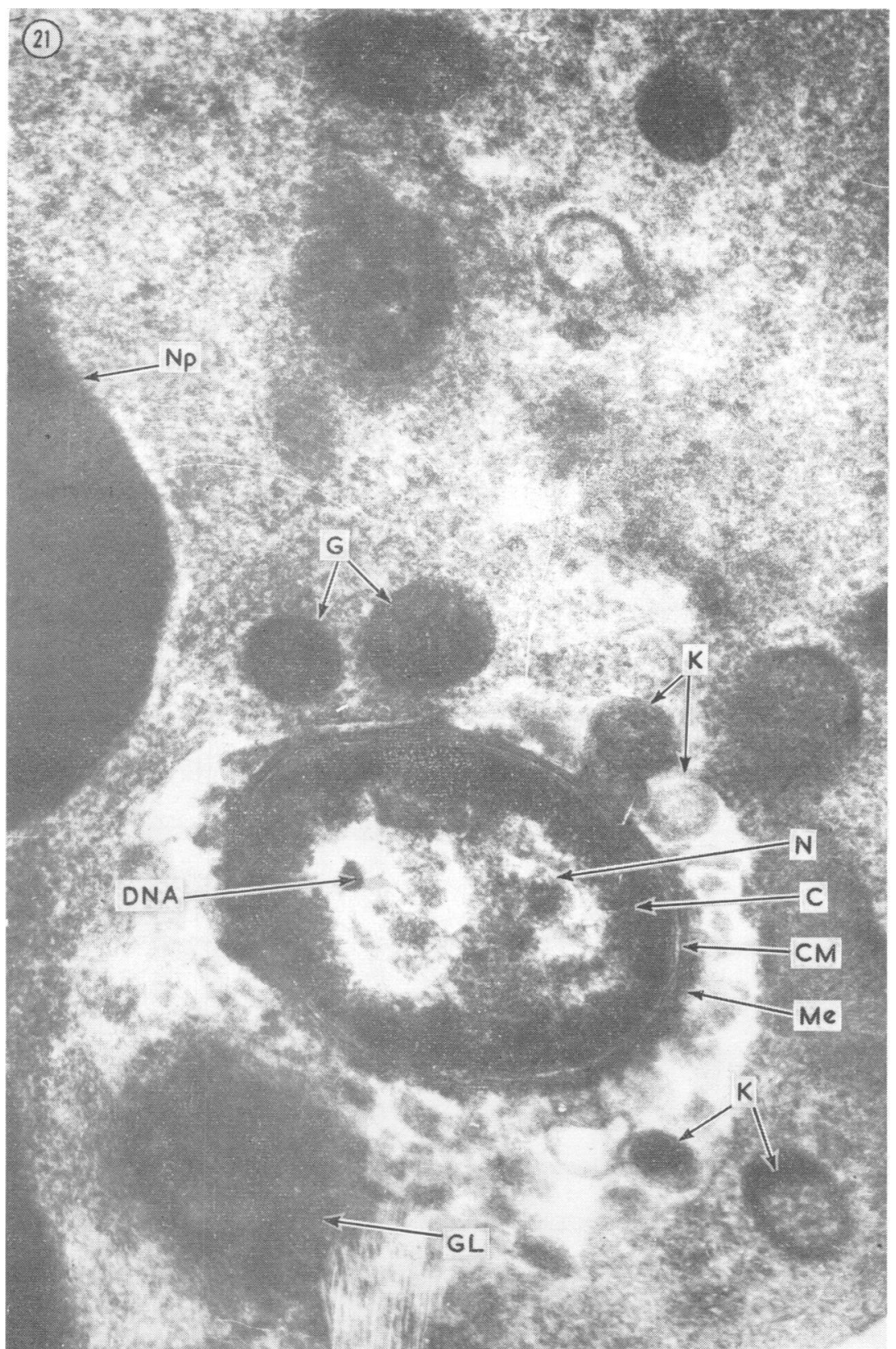

remnants of the cell wall ( $\mathrm{Me})$ and the cytoplasmic membrane (CM); in the centre are remnants of the nucleus $(N)$ with thick DNA strands and ribosomes. In the phagosome itself there is an amorphus mass and lamellar ring-like structures. In the lower part of
Fig. 21 the phagosome membrane has been destroyed $(G L)$. The granules (G) of the polymorphonuclear leucocytes are situated almost adjoining the phagosome. $\times 100,000$ 


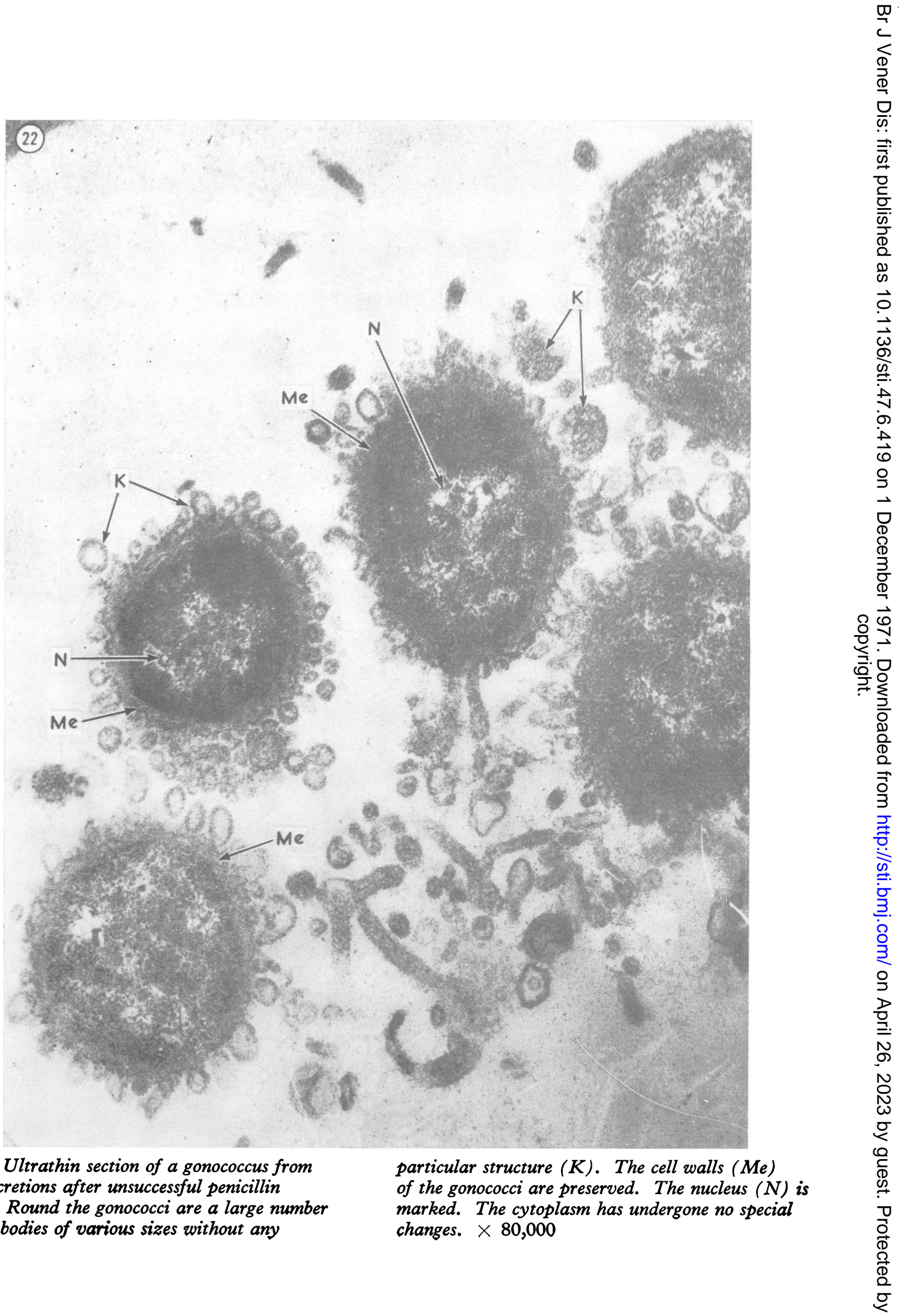

FIG. 22 Ultrathin section of a gonococcus from urethral secretions after unsuccessful penicillin treatment. Round the gonococci are a large number of circular bodies of various sizes without any 


$\begin{array}{ll}\text { C } & \text { cytoplasm } \\ \text { CH } & \text { chromatin } \\ \text { CK } & \text { membrane } \\ \text { CM } & \text { cytoplasmic membrane } \\ \text { D } & \text { homogeneous decayed mass } \\ \text { DNA } & \text { deoxyribonucleic acid } \\ \text { G } & \text { granular structure } \\ \text { GL } & \text { lysed gonococci } \\ \text { K } & \text { small circular body } \\ \text { Kg } & \text { circular granular structure } \\ \text { Ks } & \text { circular structure with limiting membrane } \\ \text { M } & \text { mesosome } \\ \text { Me } & \text { membrane, cell wall } \\ \text { Mph } & \text { phagosome } \\ \text { MN } & \text { nuclear membrane } \\ \text { MS } & \text { ring-like structure } \\ \text { N } & \text { nuclear vacuole } \\ \text { Np } & \text { nucleoplasm } \\ \text { Pl } & \text { polymorphonuclear leucocyte } \\ \text { R } & \text { ribosome } \\ \text { S } & \text { septum }\end{array}$

The cell wall of the gonococci is preserved. The cytoplasm has undergone no particular changes and the nucleus is well marked (Fig. 22).

The protective role of phagocytosis may also take the form of capturing the gonococci and not allowing them to penetrate deeply into the organism. In gonorrhoeal pus the main part in the capture of gonococci is played by the polymorphonuclear leucocytes. The other forms of leucocytes (lymphocytes and monocytes) which phagocytose the gonococci are not common in gonorrhoeal pus and we have therefore given no information concerning the part they play.

Our present researches show that a gonococcus in pus differs somewhat in morphology from a gonococcus in culture, in that the scalloped wall is different in structure. In the pus, both inside and outside cells, there are many spherical structures round the gonococcus. In cultures, such structures are seen but in considerably smaller numbers. Special attention should be paid to these rounded structures because they are apparently real gonococci. This view is supported by the fact that the larger specimens encountered in cultures have a tendency to form L-forms, and later on the L-forms themselves, at a particular stage of development, have almost the same structure. This is nothing more than the budding of the L-forms. Examinations of pus show that budding forms of gonococci are also encountered in fresh gonorrhoea. They have not been described hitherto in pus, apparently because they were taken to be structures unconnected with the gonococci. Budding as one mode of multiplication is found clearly and not infrequently in L-forms of gonococci.

It is extremely difficult to tell the altered forms of gonococci apart under the microscope. The electron micrographs also demonstrate the presence of $\mathrm{L}$ forms in pus and thus settle the dispute as to the possibility of $\mathrm{L}$-forms existing in material obtained direct from patients and not only in culture. Study of the structure of gonococcal L-forms is of particular importance, since the existence of these organisms in that state is reflected in the whole course of gonorrhoea. Diagnosis, response to antibiotics, etc., differ when $\mathrm{L}$-forms are present and when typical gonococci are present.

Successful control of communicable diseases is impossible if altered forms of micro-organisms are not taken into account. The recognition of altered forms on the basis of microscopic examination alone is also impossible. Only a well-organized culture method with material from a number of patients will make it possible to recognize these changed forms of gonococci. Hence the conclusion that for successful gonorrhoea control it is essential to introduce a cultural method for routine work in all establishments connected with control of the disease.

\section{Conclusions}

(1) In electron microscope studies of ultrathin sections of gonococci from cultures grown on ascitic agar, a scallopped three-layered outer wall and a threelayered cytoplasmic membrane are clearly visible, and between the membrane there is a finely granular mass. The cytoplasm consists of a homogeneous mass with ribosomes suspended in it. In some gonococci mesosomes are found in the form of a loop. These are continuations of the cytoplasmic membrane. The nuclear vacuole, which differs in shape and size according to the state of development of the gonococcus, is threaded with DNA strands.

(2) L-forms of the gonococci are of various sizes. Some of them are very many times larger than ordinary gonococci, while others are exceptionally small. They have a very thin outer wall. The scallopped edge has to a large extent been lost and the cytoplasm is encountered in the form of islands nearer the periphery of the gonococcus. The nucleoplasm occupies almost the whole cell and is of reticulate structure.

As well as very large specimens, a great number of small specimens with only one membrane are encountered in which the cytoplasmic substance can scarcely be seen. In some specimens the cell wall is surrounded by a large number of small forms produced by the budding of the gonococcus.

(3) The gonococcus in urethral secretions from persons suffering from fresh gonorrhoeal urethritss has a wider outer wall when situated outside the cell than a gonococcus in culture and is more 
scallopped. Quite often a large number of small forms which may or may not be connected with the outer wall are found around the gonococcus. These are produced by budding.

(4) Gonococci situated inside the polymorphonuclear leucocytes may be found both inside the phagosomes and directly in the cytoplasm. Some of them do not have any visible changes in their structure, but some are at various stages of digestion. In gonococci situated inside the cells there are sometimes a considerable number of small forms having only one membrane (sometimes three-layered), and some of these have a nucleus and a plasmatic structure (budding).

(5) The budding forms may be outside the gonococcus and also beneath the outer wall.

(6) L-forms of gonococci are found also in the urethral secretions.

\section{Summary}

The authors studied under the electron microscope ultrathin sections of gonococci in cultures and in pus from patients with fresh gonorrhoeal urethritis. The investigations showed that gonococci in pus and cultures differ somewhat in the nature of their outer wall. Extracellular gonococci are surrounded by a large number of circular structures of varying sizes and possessing a membrane. Larger structures have a nuclear vacuole with DNA strands and cytoplasm that has been crowded out towards the periphery. Similar but smaller structures are also found in gonococci inside the cells, in the phagosomes. The gonococci inside polymorphonuclear leucocytes are seen either in phagosomes with a well-marked membrane or in the cytoplasm with no marked membrane. The gonococci in the phagosomes of neutrophils sometimes look like structures resulting from decay-residual bodies. The authors suggest that in polymorphonuclear leucocytes only weakened or dead gonococci are destroyed and that the living ones continue to multiply. The rounded structures in the pus around the gonococcus are formed from the cell wall and the process by which they are formed is apparently analogous to budding in the L-forms.

The electron micrographs presented prove the existence of L-forms of gonococci in pus obtained direct from patients and thus resolve doubts whether L-forms exist in material from patients. The authors emphasize that, without taking into account changes in the shape of gonococci, successful control of gonorrhoea is impossible; it is urged that the introduction of a culture method be made obligatory for the diagnosis of gonorrhoea.

\section{References}

BRONŠTEJN, O. I. (1922) 'Endocytobiosis of the gonococcus' in 'Sbornik trudov professorov $i$ prepodavatelej Irkutskogo Universiteta (medicinskogo fakulteta)', p. 41

Fernando, N., and Movat, H. Z. (1964) Exp. molec. Path., 3,1

FronštejN, R. M. (1926) Klinika i laboratorija', in Kliničeskaja, èksperimental'naja i social'naja dermatovenereologija', pp. 309-317, Izdatel'stvo NKZ, Moscow

LUFT, J. H. (1961) F. biophys. biochem. Cytol., 9, 409

MILLONIG, G. (1961) Ibid., 11, 736

OvčrnNIKov, N. M. (1968) Akuserštvo $i$ Ginekologija, 44, no. 2 , p. 15

—, BOHENEK, A. I., and LITVAK, R. V. (1934) Urologija, 11, 1

- and Delektorskij, V. V. (1965) Vestn. Derm. Vener., 39 , no. 6 , p. 49

- (1966) WHO/VDT/RES/Gon/66.16

ReYN, A., MurRaY, A. G., AND BIRCH ANDERSON, A. A. (1963) WHO/VDT/RES/Gon/1963. 1

SabatinI, D., Bensch, K., and BARRNETt, R. (1963) $\mathcal{f}$ cell. Biol., 17, 19

Étude au microscope électronique des gonocoques des sécrétions urétrales de malades gonococciques

\section{SOMMAIRE}

Les auteurs ont étudié des coupes ultra fines, au microscope électronique, de gonocoques de culture et de gonocoques trouvés dans le pus de malades atteints d'urétrite gonococcique récente. Ces recherches ont montré que les gonocoques du pus et des cultures diffèrent quelque peu en ce qui concerne la paroi extérieure. Les gonocoques extra-cellulaires sont entourés d'un grand nombre de structures circulaires de dimension variable et possédant une membrane. Les structures les plus larges ont une vacuole nucléaire avec des brins d'ADN et le cytoplasme est tassé vers la périphérie. Des structures semblables mais plus petites furent aussi trouvées dans les gonocoques à l'intérieur des cellules dans les phagosomes. Les gonocoques à l'intérieur des lymphocytes polymorphonucléaires sont vus dans les phagosomes avec une membrane bien dessinée ou dans le cytoplasme sans membrane nette. Les gonocoques dans les phagosomes des neutrophiles ressemblent quelquefois aux structures résultant de corps résiduels altérés. Les auteurs suggèrent que, dans les polymorphonucléaires, les gonocoques seulement affablis ou morts, sont détruits et que seuls les vivants continuent à se multiplier. Les structures arrondies trouvées dans le pus autour du gonocoque sont 
formées de la paroi cellulaire et le processus par lequel celles-ci sont formées est apparemment analogue aux aspects bourgeonnantes des formes $\mathrm{L}$.

Les micro-photographies électroniques présentées prouvent l'existence de formes $\mathrm{L}$ du gonocoque dans le pus provenant directement des malades et ainsi résolvent les doutes existant quant à leur présence dans le materiel obtenu des malades.

Les auteurs font ressortir que, si l'on ne prend pas en considération les changements de dimension des gonocoques, le succès du contrôle de la gonococcie est impossible. $\overline{\bar{\omega}}$. Il est urgent de rendre obligatoire l'introduction d'une $\underset{\nabla}{\widetilde{\sigma}}$ méthode de culture dans le diagnostic de la gonococcie. 